\title{
STABILITY OF ANTHOCYANINS FROM AGRO- INDUSTRIAL RESIDUE OF ISABEL GRAPE GROWN IN SÃO FRANCISCO VALLEY, BRAZIL ${ }^{1}$
}

\author{
RAFAELLA DA SILVA BASTOS ${ }^{2}$, KARLLA KARINNE GOMES DE OLIVEIRA ${ }^{3}$, \\ ENAYDE DE ALMEIDA MELO ${ }^{4}$, VERA LÚCIA ARROXELAS GALVÃO DE LIMA ${ }^{5}$
}

ABSTRACT - Grape by-products are promising and sustainable sources of anthocyanins. Considering the factors related to degradation of those pigments, spectrophotometric and kinetic analyzes were carried out with the aim to evaluate the light and heat stability of anthocyanins from Isabel grape residue. We found that the exposure to luminosity ( $80 \mathrm{~W} ; 2500$ lux $)$ and high temperature $\left(\geq 70^{\circ} \mathrm{C}\right)$ significantly affected the absorption and content of those compounds $(\mathrm{p}<0.05)$, whose the most stable condition was obtained at $50^{\circ} \mathrm{C}\left(\mathrm{t}_{1 / 2}: 37.7 \mathrm{~h} ; \mathrm{k}: 1.84 \times 10^{-2} \mathrm{~h}^{-1}\right)$ and protected from light $\left(\mathrm{t}_{1 / 2}: 3,320.6 \mathrm{~h} ; \mathrm{k}: 2.09 \times 10^{-4} \mathrm{~h}^{-1}\right)$. Therefore, the anthocyanins from the agroindustrial residue of Isabel grape are an alternative of natural colorants for food that can be packaged in opaque packaging and not subjected to severe heat treatment during processing.

Index Terms: Vitis labrusca; Kinetics; Thermal degradation; Light.

\section{ESTABILIDADE DE ANTOCIANINAS DO RESÍDUO AGROINDUSTRIAL DA UVA ISABEL CULTIVADA NO VALE DO SÃO FRANCISCO}

RESUMO - Subprodutos da uva são fontes promissoras e sustentáveis de antocianinas. Considerando os fatores envolvidos no processo de degradação desses pigmentos, análises espectrofotométricas e cinéticas foram realizadas com o objetivo de avaliar a estabilidade à luz e ao calor de antocianinas do resíduo da uva cv. Isabel. Constatou-se que a exposição à luminosidade $(80 \mathrm{~W} ; 2500 / \mathrm{lux})$ e à temperatura elevada $\left(\geq 70^{\circ} \mathrm{C}\right)$ afetou significativamente a absorbância e o teor desses compostos ( $\mathrm{p}<0,05)$, cuja condição mais estável foi obtida a $50^{\circ} \mathrm{C}\left(\mathrm{t}_{1 / 2}: 37,7 \mathrm{~h} ; \mathrm{k}: 1,84 \times 10^{-2} \mathrm{~h}^{-1}\right)$ e protegida da luz $\left(\mathrm{t}_{1 / 2}: 3.320,6 \mathrm{~h} ; \mathrm{k}: 2,09 \times 10^{-4} \mathrm{~h}^{-1}\right)$. Portanto, as antocianinas extraídas do resíduo da uva Isabel são uma alternativa de corante natural para produtos alimentícios que sejam acondicionados em embalagens opacas e não sejam submetidos a tratamentos térmicos severos durante o processamento.

Termos para Indexação: Vitis labrusca, Cinética, Degradação térmica, Luz.

\footnotetext{
1(Paper 174-15). Received July 14, 2015. Accepted November 13, 2015.

Part of the Master's Dissertation of the first author presented to the Post-Graduate Program in Food Science and Technology (PGCTA)/ Universidade Federal Rural de Pernambuco (UFRPE).

${ }^{2}$ Nutritionist, Master in Food Science and Technology-UFRPE. E-mail: rafaellabastos@ymail.com

${ }^{3}$ Degree in Gastronomy, Master in Food Science and Technology-UFRPE. E-mail: karinnegoliveira@gmail.com

${ }^{4} \mathrm{PhD}$ in Nutrition, Full Professor, Department of Domestic Sciences, UFRPE; Av. Dom Manoel de Medeiros, s/n, Dois irmãos,

Recife-PE, Brazil, 52171-900. E-mail: enayde@hotmail.com

${ }^{5} \mathrm{PhD}$ in Nutrition, Associate Professor, Department of Domestic Sciences, UFRPE; Av. Dom Manoel de Medeiros, s/n, Dois irmãos, Recife-PE, Brazil, 52171-900. E-mail: veraarroxelas@hotmail.com
} 


\section{INTRODUCTION}

Brazil has a diversity of fruit species with agroindustrial potential. Recent data show that the country ranks the third place in the world grape production (FAO, 2015). Consequently, the region of the São Francisco Valley is an example of the growth and development of the Brazilian viticulture, since it represents a significant part of the national grape production, both in the obtaining of "in natura" fruits and in the manufacture of wines, juices and derivatives (IBGE, 2010).

Brazilian grape juices are generally produced from American hybrid grapes (Vitis labrusca); especially from the Isabel variety (LIMA et al., 2014). These handmade or commercial products contain about 30 to $470 \mathrm{mg}$ of anthocyanins $\mathrm{L}^{-1}$, and they have been increasingly valued for their positive health effects, signalizing, even, an increasing tendency of their consumption (MAIA et al., 2013).

In 2013, about 78.03 million liters of grape juice ( $92 \%$ of the whole type) were sold in Brazil, with an increase of $101.46 \%$ in relation to the average (38.73 million liters) of the previous years (2008 to 2012) (CONAB, 2013). As a result, high amount of solid waste is produced by the wine industry. However, there is no adequate infrastructure available to deal with the volume of biomass generated. Without commercial application, these by-products are discarded, without any treatment, causing serious environmental problems (MELO et al., 2011).

With the current trend in using natural pigments as dyes in food, emphasis has been given to the search for economically viable sources, especially when obtained from waste materials with sustainable appeal. In this perspective, the anthocyanins, pigments naturally present in fruits, vegetables, flowers, leaves and roots (SANTOSBUELGA; MATEUS; FREITAS, 2014) stand out and, besides the dyeing property, present possible health benefits, as a dietary antioxidant, acting in the prevention of chronic-degenerative and inflammatory diseases (YOUSUF et al., 2015).

Thus, it is possible to affirm that the limiting factor for the use of anthocyanins is their stability when compared to synthetic dyes. For this reason, researches have been conducted with the intention of minimizing color loss and investigating the factors involved in the degradation process of these compounds. In this context, the aim of this study was to evaluate the stability of anthocyanins from the agroindustrial residue of cv. Isabel cultivated in the São Francisco Valley, under the action of light and heat.

\section{MATERIALS AND METHODS}

The grape residue (Vitis labrusca, cv. Isabel, October/2013 harvest) was supplied by a manufacturing industry of whole grape juice, located in the region of the São Francisco Valley, in the city of Petrolina-PE (South Latitude 09²1'; West Longitude $40^{\circ} 40^{\prime}$; Altitude of $360 \mathrm{~m}$ ), and obtained by the hot-extraction process without bagasse pressing, as described by Lima et al. (2014). The residue was collected directly from the production line, placed in low density polyethylene bags, frozen and transported in isothermal boxes, to the Laboratory of Physical and Chemical Food Analysis, Department of Domestic Sciences, Universidade Federal Rural de Pernambuco.

Using about $50 \mathrm{~g}$ of the grape residue, the anthocyanins were extracted with acidified acetone $(0.01 \% \mathrm{HCl})$ until complete removal of these pigments. After filtration, the filtered volume was partitioned with two volumes of chloroform and stored $\left(4^{\circ} \mathrm{C} \pm 1{ }^{\circ} \mathrm{C}\right)$ for one night, allowing the separation of the polar and nonpolar phases. The aqueous phase was centrifuged $(6000 \mathrm{rpm} ; 10 \mathrm{~min}$; $\left.4^{\circ} \mathrm{C}\right)$, taken to the rotary evaporator $\left(38^{\circ} \mathrm{C} \pm 2^{\circ} \mathrm{C}\right.$ under vacuum) for the complete removal of residual acetone. The anthocyanins present in the aqueous phase were purified by solid phase extraction (SPE) using 600mg $\mathrm{C}_{18}$ cartridges (Alltech Assoc., Inc., Illinois, USA) for the removal of sugars, acids and other non-anthocyanin phenolic compounds (RODRIGUEZ-SAONA; WROLSTAD, 2001). The resulting methanolic extract was concentrated in vacuum in a rotary evaporator $\left(38^{\circ} \mathrm{C} \pm 2^{\circ} \mathrm{C}\right)$ until the acquisition of a dry residue to which diethyl ether was added in order to precipitate the pigments (ESPÍN et al., 2000). All procedures were carried out under conditions of reduced light incidence.

For the light stability study, purified anthocyanins were diluted in $95 \%$ ethanol solution $(\mathrm{HCl} 1.5 \mathrm{~N} ; 85: 15 \mathrm{v} / \mathrm{v} ; \mathrm{pH} 1.0)$ at a concentration of $0.1 \mathrm{mg} . \mathrm{mL}^{-1}$, and distributed in 12 clear test tubes $(20 \mathrm{~mL})$ with rubber lids, maintained at $21^{\circ} \mathrm{C}$ $\pm 1^{\circ} \mathrm{C}$. Six tubes were exposed to fluorescent light (80W; 2500 lux) at a distance of $1.45 \mathrm{~m}$ between the light source and the tubes, and the other six tubes were carefully covered with aluminum foil and left in a dark place, protected from light. Absorbance readings of the anthocyanins solution were recorded at $535 \mathrm{~nm}$ (LEES; FRANCIS, 1972) periodically for 840 hours ( 35 days), and the data obtained were used to calculate the speed constant $(\mathrm{k})$ and half-life time $\left(t_{1 / 2}\right)$ of the anthocyanins by means of the following kinetic equations: 


$$
\begin{gathered}
-\ln \left(\frac{\text { Absorbance }(\mathrm{t})}{\text { Absorbance }\left(\mathrm{t}_{0}\right)}\right)=\mathrm{kt} \\
\mathrm{t}_{1 / 2}=\frac{\ln 2}{\mathrm{k}}
\end{gathered}
$$

(Equation 2)

Where: Absorbance $(\mathrm{t})$ : absorption in relation to time; Absorbance $\left(\mathrm{t}_{0}\right)$ : absorption in 'zero' time; $\mathrm{t}$ : time (hours); $\mathrm{k}$ : speed constant; $\mathrm{t}_{1 / 2}$ : half-life time.

The heat effect on the stability of the purified anthocyanins was monitored using 15 threaded test tubes covered with aluminum foil containing $15 \mathrm{ml}$ of anthocyanins in aqueous solution acidified with $\mathrm{HCl}(\mathrm{pH} \mathrm{1.0)}$, prepared in a concentration of 0.1 $\mathrm{mg} . \mathrm{mL}^{-1}$, which were submitted to heating at $50^{\circ} \mathrm{C}$, $70^{\circ} \mathrm{C}$ and $90^{\circ} \mathrm{C}$, in thermostated bath with water circulation, during the periods of $1,3,5$ and 7 hours. Absorption readings were performed on the freshly prepared sample $(0 \mathrm{~h})$, at room temperature $\left(22^{\circ} \mathrm{C} \pm\right.$ $2^{\circ} \mathrm{C}$, control), and after each heating period. After the predetermined intervals, the samples were removed from the thermostated bath and cooled in an ice bath at room temperature.

The aqueous solution of anthocyanins was appropriately diluted in buffers at $\mathrm{pH} 1.0$ (potassium chloride, $0.025 \mathrm{M}$ ) and $\mathrm{pH} 4.5$ (potassium acetate, $0.4 \mathrm{M}$ ). After $15 \mathrm{~min}$ of rest, absorption readings were performed at $520 \mathrm{~nm}$ and $700 \mathrm{~nm}$ in a spectrophotometer (Shimadzu UV-1650PC) in cuvettes of $1 \mathrm{~cm}$ optical path and calculated according to the equation below (LEE; DURST; WROLSTAD, 2005):

$$
A=\left(A_{520 \mathrm{~nm}}-A_{700 \mathrm{~nm}}\right)_{\mathrm{pH} 1.0}-\left(\mathrm{A}_{520 \mathrm{~nm}}-\mathrm{A}_{700 \mathrm{~nm}}\right)_{\mathrm{pH} 4.5}
$$

The absorption values were used to calculate the speed constant $(\mathrm{k})$ and the half-life time $\left(\mathrm{t}_{1 / 2}\right)$ of the anthocyanins by kinetic equations 1 and 2 .

The anthocyanins content was determined according to the differential $\mathrm{pH}$ method (LEE; DURST; WROLSTAD, 2005), considering the molar absorptivity $(\varepsilon)$ of $28,000 \mathrm{~L} \cdot \mathrm{cm}^{-1} \cdot \mathrm{mol}^{-1}$ and the molecular weight of 493.2 g. $\mathrm{mol}^{-1}$ of malvidin 3-glycoside, and the results were expressed in mg.L $\mathrm{L}^{-1}$, applying the following formula:

Monomeric anthocyanins $=\mathrm{A} \times \mathrm{MW} \times \mathrm{DF}$ X $1000 / \varepsilon \times 1$

Where: $\mathrm{A}=\left(\mathrm{A}_{520 \mathrm{~nm}}-\mathrm{A}_{700 \mathrm{~nm}}\right)_{\mathrm{pH} 1.0}-\left(\mathrm{A}_{52 \mathrm{~nm}}-\mathrm{A}_{700 \mathrm{~nm}}\right)_{\mathrm{pH} 4.5}$ $\mathrm{MW}=$ molecular weight; $\mathrm{DF}=$ dilution factor; $\varepsilon=$ molar absorptivity.

The experiment was set up according to a completely randomized experimental design. All the determinations were performed in triplicate and the results submitted to the Tukey test at 5\% probability level ( $\mathrm{p}<0.05)$ using "Statistica" software (version 7, StatSoft, Inc., Tulsa, USA).

\section{RESULTS AND DISCUSSION}

In the absence of light, the anthocyanins absorption of cv. Isabel grape residue differed significantly ( $\mathrm{p}<0.05$ ) up to $98 \mathrm{~h}$ ( 4 days). However, did not present a statistically significant difference between the intervals of $98 \mathrm{~h}$ ( 4 days) to $432 \mathrm{~h}$ (18 days) and then until the final time of $840 \mathrm{~h}$ (35 days), demonstrating stability in both conditions. On the other hand, samples submitted to light differed significantly $(\mathrm{p}<0.05)$ during the entire storage period at $21^{\circ} \mathrm{C} \pm 1{ }^{\circ} \mathrm{C}$, except in the last two periods (Table 1). Thus, the tested anthocyanins remained more stable protect from light than when subjected to light.

The speed constants $(\mathrm{k})$ were $2.09 \times 10^{-4} \mathrm{~h}^{-1}$ and $1.37 \times 10^{-3} \mathrm{~h}^{-1}$ for light-protected anthocyanins and exposed to light anthocyanins, respectively. These results revealed that the degradation speed of light-protected anthocyanins was lower than when exposed to light. The $50 \%$ loss of the initial absorbance (half-life time) occurred after $505.8 \mathrm{~h}$ (21 days) for the anthocyanins subjected to the light effect, and it would therefore occur after 3,320.6h (138 days) for the samples protected from light, showing the greatest instability of anthocyanins to light.

In this study, the half-life time of the purified anthocyanins exposed to light was lower than the crude anthocyanins extract of purple Surinam cherry (948h; 39 days) in a study conducted by Lima, Mélo and Lima (2005). The greatest light sensitivity of purified anthocyanins, when compared to a crude extract solution, can be justified by the non-formation of complexes with other constituents of the extract (such as flavonoids), since they could act as copigments, promoting color stabilization (CLIFFORD, 2000; MANACH et al., 2004). In the fractions of purified anthocyanins, other flavonoids that would naturally be present in the crude extract are reduced; contributing to the susceptibility of the anthocyanins to the effect of luminosity, and thus, the decomposition is accentuated according to the degree of purification of the pigments (STRINGHETA; BOBBIO, 2000).

On the other hand, in this study, the halflife time of anthocyanins protected from light $(3,320.6 \mathrm{~h} ; 138$ days) was higher than the half-life 
time of anthocyanins present in the crude extract of purple Surinam cherry $(1,205.7 \mathrm{~h} ; 50$ days) (LIMA, MÉLO; LIMA, 2005), highlighting the influence of the chemical structure on the stability and, therefore, the color and reactivity of these pigments by the presence of sugars, acylated sugars, methoxyl and hydroxyl groups. As the degree of hydroxylation is high, blue shades are produced, while the higher methoxylation degree produce red shades (VARGAS Y VARGAS et al., 2013). Under light exposure, anthocyanins glycosides were considered more stable than monoglycosides (ZHAO et al., 2014).

When studying the effect of light, oxygen and $\mathrm{pH}$ on the anthocyanic extract obtained from the skin of the capuli fruit (Prunus serotina spp capuli (Cav) Mc Vaug Cav), Hurtado and Pérez (2014) reported different half-life times for the samples in the presence of light and oxygen at pH $3.0(2,520 \mathrm{~h}$; 105 days) and $\mathrm{pH} 5.0$ (1,205h; 50 days $)$, as well as in the absence of the same variables, at $\mathrm{pH} 3.0(8,755 \mathrm{~h}$; 365 days) and $\mathrm{pH} 5.0$ (3,326h; 139 days), indicating the $\mathrm{pH}$ and the light as important interfering factors in the color of anthocyanins, intensifying even more when associated with oxygen. Therefore, from the practical point of view, the anthocyanins have restricted application to acidic products, considering that the $\mathrm{pH}$ affects both the tonality and the intensity of the coloration.

Gómez-Plaza, Miñano and López-Roca (2006) studying the color stability of anthocyanic aqueous extracts obtained from grape residues (Vitis vinifera L.), also determined its instability in relation to the $\mathrm{pH}$ and the presence of light, being, in the last, a marked reduction in absorbance when compared to the samples that were kept protected from light. This result ratifies the data that expose the loss of absorbance of the anthocyanins of the cv. Isabel grape residue (Table 1), which was evaluated in $16.08 \%$, in the absence of light, and $68.43 \%$ in the presence of light (2500 lux). Similar reduction (65.86\%) in the anthocyanin content was determined by Mayavel et al. (2012) in acidified metanolic red tamarind extract at 500 lux intensity during a storage period of 30 days. The authors also highlighted a color loss of the pigment stored protected from the light (39.71\%), at 250 lux intensity $(45.10 \%)$ and more significant loss during exposure to direct sunlight (93.48\%). The drastic loss observed in the last condition may have occurred due to the combined action of the high intensity of light and temperature, optimizing the degradation of anthocyanin molecules.

In this study, it was possible to verify that the degradation mechanism of the anthocyanins of the cv. Isabel grape residue is temperature dependent, according to the kinetic parameters evaluated (Table $2)$, whose anthocyanin absorbance values differed significantly $(p<0.05)$ as the temperature and time of exposure increased. The speed constants $(\mathrm{k})$ were the following: $1.84 \times 10^{-2} \mathrm{~h}^{-1}\left(50^{\circ} \mathrm{C}\right) ; 7.82 \times 10^{-2} \mathrm{~h}^{-1}\left(70^{\circ} \mathrm{C}\right)$; $1.99 \times 10^{-1} \mathrm{~h}^{-1}\left(90^{\circ} \mathrm{C}\right)$; therefore, the half-life time of the samples occurred after $3.5 \mathrm{~h}$ at $90^{\circ} \mathrm{C}$, and would occur after $8.9 \mathrm{~h}$ and $37.7 \mathrm{~h}$, for the samples at $70^{\circ} \mathrm{C}$ and $50^{\circ} \mathrm{C}$, proving that the anthocyanin pigments are degradable by the action of high temperatures, with the strongest deleterious effect evidenced at the highest temperature.

Sadilova, Stintzing and Carle (2006) studying the similar conditions obtained the following half-lives times for purified anthocyanins from: elderberry (1.9h), strawberry (3.2h) and black carrot (4.1h) during heating at $95^{\circ} \mathrm{C}(\mathrm{pH} 1.0)$, whose differences are explained by different chemical structures of anthocyanins, specific to each plant source. According to Zorić et al. (2014), the thermal degradation of anthocyanins is mainly caused by oxidation reactions and cleavage of covalent bonds. In a review on the subject, Malacrida and Motta (2006) suggest that glycosidic hydrolysis as the main reason for anthocyanins color loss, considering that the rate of sugar release is proportional to the speed of red color loss. On the other hand, the occurrence of acylation in the molecule promotes its stabilization and, consequently, color retention, even under the action of environmental factors such as heating and light (KOLEY et al., 2014).

The thermal degradation of anthocyanins from the cv. Isabel grape residue is graphically represented as a function of time (Figure 1). The anthocyanins concentration of this residue, in acidified aqueous solution $(\mathrm{pH} 1.0)$ during the heating, differed significantly $(\mathrm{p}<0.05)$ among the tested temperatures. When evaluated over the heating time, the anthocyanin content in the experiment at $50^{\circ} \mathrm{C}$ did not show statistically significant difference ( $p<0.05$ ) up to 3 hours in relation to the control $\left(22^{\circ} \mathrm{C} \pm 2{ }^{\circ} \mathrm{C}\right)$, showing stability in this condition. The samples submitted to temperatures of $70^{\circ} \mathrm{C}$ and $90^{\circ} \mathrm{C}$ showed similar behavior, differing significantly from the control $(\mathrm{p}<0.05)$ after 1 hour of heating. After this time, we observed a drastic reduction of anthocyanin content at both temperatures $\left(70^{\circ} \mathrm{C}\right.$ and $90^{\circ} \mathrm{C}$ ). In this way, it is possible to verify the deleterious effect of high temperatures under the stability of the tested anthocyanins.

Canuto et al. (2016) also reported in their strawberry study the instability of anthocyanins in high temperatures $\left(\geq 80^{\circ} \mathrm{C}\right)$. Dyrby, Westergaard and Stapelfeldt (2001) compared the thermal stability 
(pH 3.0) of four different commercial extracts and, for the studied temperatures $\left(25^{\circ} \mathrm{C}, 40^{\circ} \mathrm{C}, 60^{\circ} \mathrm{C}\right.$ and $80^{\circ} \mathrm{C}$ ), the degree of stability was higher in purple cabbage, followed by gooseberry residue, grape and elderberry skin. In addition to the concentration, chemical structure, temperature, $\mathrm{pH}$, presence of light and oxygen, the stability of these pigments also depends on the interaction with other components of the system, such as solvents, enzymes, other flavonoids, proteins and metal ions (RODRIGUEZAMAYA, 2016).

Structurally, the degradation is prevented by glycosylation, generally with a glucose in the position 3 , and esterification with various organic acids (citric and malic) and phenolic acids (CLIFFORD, 2000; MANACH et al., 2004). In addition, the presence of more hydroxyl groups is related to the instability and, contrarily, the higher degree of methoxylation confers more stability to the molecular structure (FRANCIS, 1989).

A study conducted by Bordignon-Luiz et al. (2007), in a food model system, showed that the crude extract of cv. Isabel grape is relatively stable in yogurt. Several conditions were tested, with the longest half-life time $(1,514 \mathrm{~h})$ observed under conditions of $\mathrm{pH}(3.0)$, temperature $\left(7^{\circ} \mathrm{C} \pm 1^{\circ} \mathrm{C}\right)$, protected from light, in the presence of oxygen and with the addition of tannic acid, demonstrating that it is possible to increase the half-life of anthocyanins by controlling the various factors associated with the degradation of these pigments.

TABLE 1 - Loss of absorption of anthocyanins* from agroindustrial residue of cv. Isabel grape submitted to the presence and absence of light $\left(\mathrm{T}=21^{\circ} \mathrm{C} \pm 1^{\circ} \mathrm{C}\right)$.

\begin{tabular}{ccccc}
\hline \multirow{2}{*}{ Time (hours) } & \multicolumn{2}{c}{ Presence of light } & \multicolumn{2}{c}{ Absence of light } \\
\cline { 2 - 5 } & $\mathbf{A b s * *}(\mathbf{5 3 5} \mathbf{~ n m})$ & Loss (\%) & $\left.\mathbf{A b s}^{* *} \mathbf{( 5 3 5} \mathbf{~ n m}\right)$ & Loss (\%) \\
\cline { 2 - 5 } 0 & $0.944 \pm 0.001^{\mathrm{a}}$ & - & $0.945 \pm 0.004^{\mathrm{a}}$ & - \\
24 & $0.851 \pm 0.009^{\mathrm{b}}$ & 9.85 & $0.862 \pm 0.012^{\mathrm{b}}$ & 8.78 \\
98 & $0.727 \pm 0.014^{\mathrm{c}}$ & 22.99 & $0.825 \pm 0.003^{\mathrm{c}}$ & 12.70 \\
240 & $0.565 \pm 0.016^{\mathrm{d}}$ & 40.15 & $0.822 \pm 0.014^{\mathrm{c}}$ & 13.02 \\
432 & $0.444 \pm 0.017^{\mathrm{e}}$ & 52.97 & $0.819+0.009^{\mathrm{cd}}$ & 13.33 \\
576 & $0.378 \pm 0.018^{\mathrm{f}}$ & 59.96 & $0.811 \pm 0.008^{\mathrm{d}}$ & 14.18 \\
720 & $0.326 \pm 0.022^{\mathrm{g}}$ & 65.47 & $0.795 \pm 0.019^{\mathrm{d}}$ & 15.87 \\
840 & $0.298 \pm 0.015^{\mathrm{g}}$ & 68.43 & $0.793 \pm 0.020^{\mathrm{d}}$ & 16.08 \\
\hline
\end{tabular}

$(*)$ Anthocyanins in ethanol solution at $95 \%(\mathrm{HCl} 1.5 \mathrm{~N} ; 85: 15 \mathrm{v} / \mathrm{v} ; \mathrm{pH} 1.0) .\left({ }^{* *}\right)$ Values represent average of absorbance readings in six tubes. Averages followed by the same letter in columns do not differ from each other by Tukey test $(\mathrm{p}>0.05)$.

TABLE 2 - Kinetic parameters of thermal degradation of anthocyanins* from agroindustrial residue of cv. Isabel grape.

\begin{tabular}{ccccc}
\hline Temperature $\left({ }^{\circ} \mathbf{C}\right)$ & Time (hours) & $\mathbf{A b s}^{* *}$ & $\mathbf{K}\left(\mathbf{h}^{-1}\right)$ & $\mathbf{t}_{1 / 2}$ (hours) \\
\hline & 0 & $0.846 \pm 0.021^{\mathrm{a}}$ & & \\
50 & 1 & $0.813 \pm 0.003^{\mathrm{a}}$ & & \\
& 3 & $0.801 \pm 0.018^{\mathrm{ab}}$ & $1.84 \times 10^{-2}$ & 37.66 \\
& 5 & $0.753 \pm 0.039^{\mathrm{b}}$ & & \\
& 7 & $0.744 \pm 0.013^{\mathrm{b}}$ & & \\
70 & 0 & $0.840 \pm 0.014^{\mathrm{a}}$ & & \\
& 1 & $0.720 \pm 0.018^{\mathrm{b}}$ & & \\
& 3 & $0.669 \pm 0.014^{\mathrm{b}}$ & $7.82 \times 10^{-2}$ & \\
& 5 & $0.507 \pm 0.032^{\mathrm{c}}$ & & \\
& 7 & $0.486 \pm 0.040^{\mathrm{c}}$ & & \\
& 0 & $0.837 \pm 0.039^{\mathrm{a}}$ & & \\
& 1 & $0.663 \pm 0.009^{\mathrm{b}}$ & & \\
& 3 & $0.327 \pm 0.042^{\mathrm{c}}$ & $1.99 \times 10^{-1}$ & \\
& 5 & $0.237 \pm 0.039^{\mathrm{cd}}$ & & \\
& 7 & $0.207 \pm 0.027^{\mathrm{d}}$ & & \\
\hline
\end{tabular}

(*) Anthocyanins in aqueous solution acidified with $\mathrm{HCl}(\mathrm{pH}$ 1.0). Abs: absorption; K: speed constant of degradation; $\mathrm{t} 1 / 2$ : half-life $\left.\mathrm{e} ;{ }^{* *}\right) \mathrm{Abs}=(\mathrm{A} 520 \mathrm{~nm}-\mathrm{A} 700 \mathrm{~nm}) \mathrm{pH} 1.0-(\mathrm{A} 520 \mathrm{~nm}-\mathrm{A} 700 \mathrm{mn}) \mathrm{pH} 4.5$. Averages in columns, in each temperature, followed by the same letter do not differ from each other by Tukey test $(\mathrm{p}>0.05)$. 


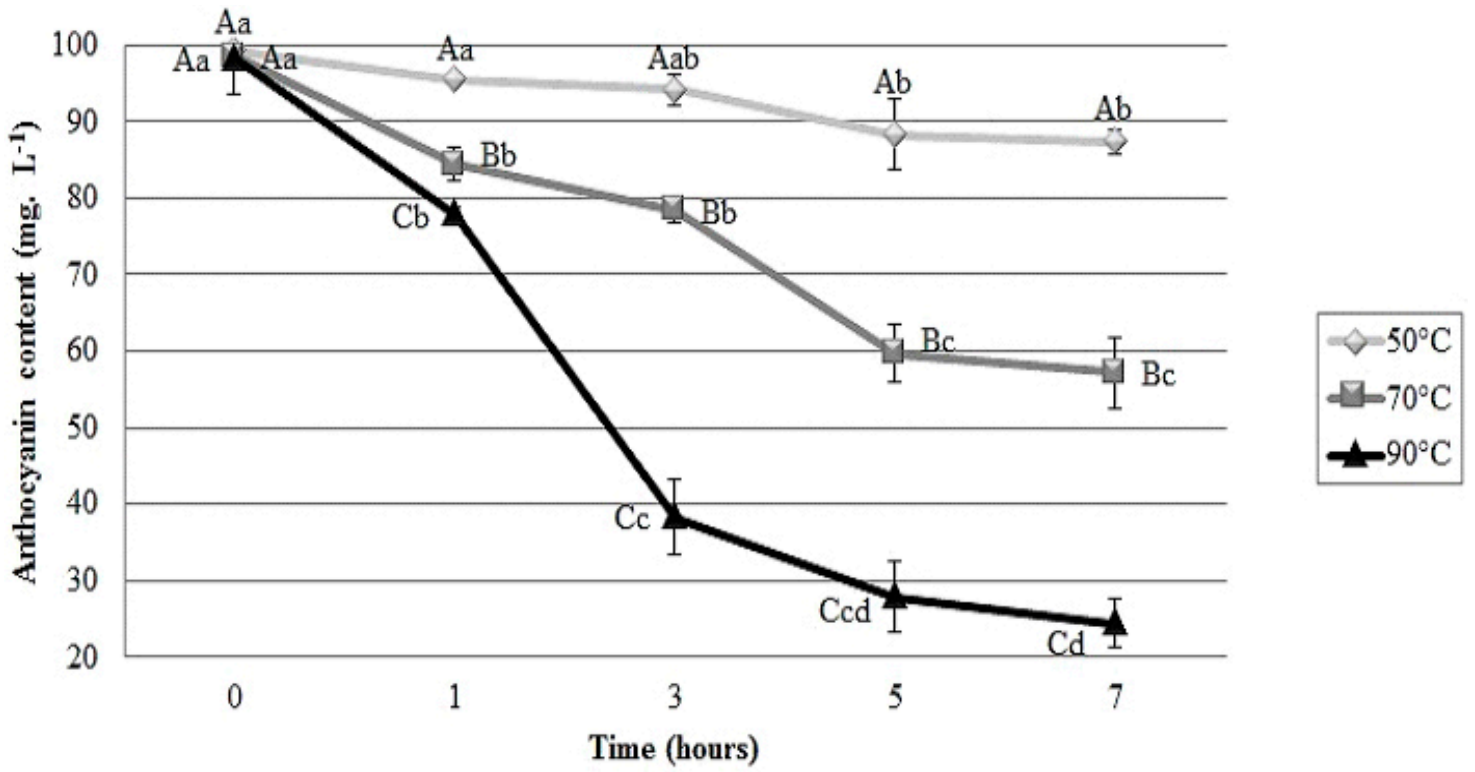

FIGURE 1 - Thermal degradation of anthocyanins from agroindustrial residue of cv. Isabel grape.

Different upper case letters indicate significant difference between tested temperatures and different lowercase letters indicate significant difference caused by heating over time by the Tukey's test at $5 \%$ probability.

\section{CONCLUSIONS}

The results allow concluding that the anthocyanins of the agroindustrial residue of $\mathrm{cv}$. Isabel grape have limited stability to luminosity exposure and high temperature, with the longer half-life time and lower degradation speed of these pigments evidenced at $50^{\circ} \mathrm{C}$ and protected from light. In this sense, these anthocyanins are an option for the reuse of grape by-products when associated with the control of these variables, and therefore, they consist of a use alternative for the food industry, as a natural dye, with potential application in food products with acidic $\mathrm{pH}$, which are packaged in opaque packaging and which do not undergo severe heat treatments during processing.

\section{ACKNOWLEDGEMENTS}

We thank to UFRPE (Universidade Federal Rural de Pernambuco) for the financial support and to CAPES (Coordenação de Aperfeiçoamento de Pessoal de Nível Superior) for granting the scholarships. The authors are also thankful to the "Embrapa Semiárido" (Petrolina-PE) and "Nova Aliança Agricultural Cooperative" (COANA) for the support and supply of the samples..

\section{REFERENCES}

BORDIGNON-LUIZ, M. T.; GAUCHE, C.; GRIS, E. F.; FALCÃO, L. D. Colour stability of anthocyanins from Isabel grapes (Vitis labrusca L.) in model systems. LWT-Food Science and Technology, Zürich, v. 40, n. 4, p. 594-599, 2007.

CANUTO, G. A. B.; OLIVEIRA, D. R.; CONCEIÇÃO, L. S. M.; FARAH, J. P. S.; TAVARES, M. F. M. Development and validation of a liquid chromatography method for anthocyanins in strawberry (Fragaria spp.) and complementary studies on stability, kinetics and antioxidant power. Food Chemistry, London, v. 192, p. 566-574, 2016.

CLIFFORD, M. N. Anthocyanins - nature, occurrence and dietary burden. Journal of the Science of Food and Agriculture, London, v. 80, n. 7, p. 1063-1072, 2000 .

CONAB - Companhia Nacional de Abastecimento. Conjuntura mensal: derivados da uva. Período: jan. a dez. de 2013. Disponível em: $<$ http://www.conab.gov.br/OlalaCMS/ uploads/arquivos/14_05_06_16_47_31 derivadosdauvajaneiroadezembro2013.pdf $>$. Acesso em: 2 maio 2014 
DYRBY,M.; WESTERGAARD, N.; STAPELFELDT, $H$. Light and heat sensitivity of red cabbage extract in soft drink model systems. Food Chemistry, London, v.72, n.4, p.431-437, 2001.

ESPÍN, J. C.; SOLER-RIVAS, C.; WICHERS, H. J.; GARCÍA-VIGUERA, C. Anthocyanin-based natural colorants: a new source of antiradical activity for foodstuff. Journal of Agricultural and Food Chemistry, Washington, v.48, n.5, p.1588-1592, 2000 .

FAO - Food and Agriculture Organization of the United Nations. FAOSTAT: food and agricultural commodities production: Item grapes, Year 2013. Disponível em: <http://faostat3.fao.org/browse/ rankings/countries by commodity/E>. Acesso em: 13 jun. 2015.

FRANCIS, F. J. Food colorants: anthocyanins. Critical Reviews in Food Science and Nutrition, Philadelphia, v. 28, n. 4, p. 273-314, 1989.

GÓMEZ-PLAZA, E.; MIÑANO,A.; LÓPEZ-ROCA, J. M. Comparison of chromatic properties, stability and antioxidant capacity of anthocyanin-based aqueous extracts from grape pomace obtained from different vinification methods. Food Chemistry, London, v.97, n.1, p.87-94, 2006.

HURTADO, N.H.; PÉREZ, M. Identificación, estabilidad y actividad antioxidante de las antocianinas aisladas de la cáscara del fruto de capulí (Prunus serotina spp capuli (Cav) Mc. Vaug Cav). Información Tecnológica, La Serena, v.25, n.4, p.131-140, 2014.

IBGE - Instituto Brasileiro de Geografia e Estatística. Produção agrícola municipal: culturas temporárias e permanentes. Rio de Janeiro: IBGE, 2010. v. 37, 91p. Disponível em: <http://biblioteca.ibge.gov.br/ visualizacao/periodicos/66/pam 2010 v37 br.pdf $>$. Acesso em: 13 abr. 2013.

LEE, J.; DURST, R.W.; WROLSTAD, R.E. Determination of total monomeric anthocyanin pigment content of fruit juices, beverages, natural colorants, and wines by the ph differential method: collaborative study. Journal of AOAC International, Rockville, v.88, n.5, p.1269-1278, 2005.
LEES, D.H.; FRANCIS, F.J. Standardization of pigment analysis in cranberries. HortScience, Pleasanton, v. 7, n. 1, p. 83-84, 1972.

LIMA, M. S.; SILANI, I. S. V.; TOALDO, I. M.; CORRÊA, L. C.; BIASOTO, A. C. T.; PEREIRA, G. E.; BORDIGNON-LUIZ, M. T.; NINOW, J. L. Phenolic compounds, organic acids and antioxidant activity of grape juices produced from new Brazilian varieties planted in the Northeast Region of Brazil. Food Chemistry, London, v.161, p.94-103, 2014.

KOLEY, T. K.; SINGH, S.; KHEMARIYA, P.; SARKAR, A.; KAUR, C.; CHAURASIA, S. N. S.; NAIK, P. S. Evaluation of bioactive properties of Indian carrot (Daucus carota L.): a chemometric approach. Food Research International, New York, v.60, p.76-85, 2014.

LIMA, V.L.A.G., MÉLO, E.A.; LIMA, D.E.S. Efeito da luz e da temperatura de congelamento sobre a estabilidade das antocianinas da pitanga roxa. Ciência e Tecnologia de Alimentos, Campinas, v. 25, n. 1, p. 92-94, 2005.

MAIA, J.D.G.; PEREIRA; G.E.; MONTEIRO; F.P.; SOUZA, R.T.; LAZZAROTTO, J.J.; OLIVEIRA, J.B.; RITACHEL, P. Novas cultivares brasileiras de uvas para elaboração de suco no semiárido brasileiro: desempenho agronômico e qualidade do suco. Bento Gonçalves: Embrapa Uva e Vinho, 2013. 24p. (Circular Técnica, 96). Disponível em: $<$ http:// www.cnpuv.embrapa.br/publica/circular/cir096. pdf $>$. Acesso em: 17 abr. 2014.

MALACRIDA, C. R.; MOTTA, S. Antocianinas em suco de uva: composição e estabilidade. Boletim do Centro de Pesquisa de Processamento de Alimentos (CEPPA), Curitiba, v. 24, n. 1, p. 59-82, 2006.

MANACH, C.; SCALBERT, A.; MORAND, C.; RÉMÉSY, C.; JIMÉNEZ, L. Polyphenols: food sources and bioavailability. The American Journal of Clinical Nutrition, Bethesda, v. 79, n. 5, p. 727 $747,2004$. 
MAYAVEL, A.; GURUDEV SINGH, B.; DURAI, A.; MURUGEASAN, S. Evaluation of colour and stability of anthocyanin in red tamarind (Tamarindus indica L). International Journal of Advanced Life Sciences, Coimbatore, v.5, n.2, p.137-144, 2012.

MELO, P. S.; BERGAMASCHI, K. B.; TIVERON, A. P.; MASSARIOLI, A. P.; OLDONI, T. L. C.; ZANUS, M. C.; PEREIRA; G. E.; ALENCAR, S. M. Composição fenólica e atividade antioxidante de resíduos agroindustriais. Ciência Rural, Santa Maria, v.41, n.6, p.1088-1093, 2011.

RODRIGUEZ-AMAYA, D. B. Natural food pigments and colorants. Current Opinion in Food Science, Amsterdam, v.7, p.20-26, 2016.

RODRIGUEZ-SAONA, L. E.; WROLSTAD, R. E. Extraction, isolation, and purification of anthocyanins. In: WROLSTAD, R. E. Current protocols in food analytical chemistry. New York: John Wiley \& Sons, 2001. p. F1.1.1-F1.1.10.

SADILOVA, E.; STINTZING, F. C.; CARLE, R. Thermal degradation of acylated and nonacylated anthocyanins. Journal of Food Science, Malden, v.71, n.8, 2006.

SANTOS-BUELGA, C.; MATEUS, N.; FREITAS, V. Anthocyanins. Plant Pigments and Beyond. Journal of Agricultural and Food Chemistry, Washington, v.62, p.6879-6884, 2014.
STRINGHETA, P. C.; BOBBIO, P. A. Copigmentação de antocianinas: uso de corantes naturais em alimentos processados. Biotecnologia Ciência $\&$ Desenvolvimento, Brasília, DF, v.3, n.14, p.34-37, 2000.

VARGAS Y VARGAS, M. L.; CORTEZ, J. A. T.; DUCH, E. S.; LIZAMA, A. P.; MÉNDEZ, C. H. H. Extraction and stability of anthocyanins present in the skin of the dragon fruit (Hylocereus undatus). Food and Nutrition Sciences, Irvine, v.4, p.12211228, 2013.

YOUSUF, B.; GUL, K.; WANIA.A.; SINGH,P. Health benefits of anthocyanins and their encapsulation for potential use in food systems: a review. Critical Reviews in Food Science and Nutrition, Boca Raton, 2015. Disponível em: $<$ http://dx.doi.org/urn :doi:10.1080/10408398.2013.805316>.

ZHAO C. L.; CHEN Z. J.; BAI, X. S.; DING, C.; LONG, T. J.; WEI, F. G.; MIAO, K. R. Structureactivity relationships of anthocyanidin glycosylation. Molecular Diversity, Leiden, v.18, n.3, p.687-700, 2014.

ZORIĆ, Z.; DRAGOVIĆ-UZELAC, V.; PEDISIĆ, S.; KURTANJEK, Z.; GAROFULIC, I. E. Kinetics of the degradation of anthocyanins, phenolic acids and flavonols during heat treatments of freeze-dried sour cherry Marasca paste. Food Technology and Biotechnology, Zagreb, v.52, n.1, p.101-108, 2014. 